\section{Nitrogen Fertilizer Management and Cultivar Selection for Cabbage Production in the Southeastern United States}

\author{
Andre Luiz Biscaia Ribeiro da Silva ${ }^{1}$, Joara Secchi Candian ${ }^{1}$, \\ Lincoln Zotarelli ${ }^{2}$, Timothy Coolong ${ }^{1}$, \\ and Christian Christensen ${ }^{2}$
}

ADDITIONAL INDEX WORDs. Brassica olevacea var. capitata, cabbage yield, head quality, nitrogen leaching, rainfall

SumMARY. Soil nitrogen (N) is easily leached in cabbage (Brassica olevacea var. capitata) production areas of southeastern United States characterized by sandy soils with low water-holding capacity. Soil $\mathrm{N}$ leaching in these areas is increased after rainfall events; consequently, growers increase the fertilizer $\mathrm{N}$ application to protect against $\mathrm{N}$ deficiencies and yield loss. The objective of this study was to evaluate the effects of three fertilizer $\mathrm{N}$ rates on yield and head quality for common cabbage cultivars used by Florida and Georgia growers during four cabbage growing seasons. Field experiments were conducted in Hastings, FL, in 2016 and 2017, and in Tifton, GA, in 2018 and 2019. A randomized complete block design was used with a split-plot design of fertilizer $\mathrm{N}$ rate and cabbage cultivar. Fertilizer $\mathrm{N}$ rate treatments consisted of the application of 170 , 225, and $280 \mathrm{lb} /$ acre $\mathrm{N}$ and were assigned as the main plot. Cabbage cultivars Bravo, Bronco, Bruno, Capture, Cheers, and Ramada were assigned as the sub-plots. Weather conditions were monitored during all growing seasons, and total, marketable, and unmarketable yields, as well as cabbage head polar and equatorial diameters, and core height and width were measured. In Florida, there was a significant interaction for growing season and fertilizer $\mathrm{N}$ rate. The Florida 2016 cabbage season experienced 10.5 inches of rainfall, and fertilizer $\mathrm{N}$ rates had no effect on cabbage yields. Total and marketable yield averaged 45,391 and 38,618 lb/acre among fertilizer $\mathrm{N}$ rates in 2016, respectively. Rainfall accumulated 2.1 inches during the 2017 study in Florida, which was less than the crop evapotranspiration. In response, total and marketable yield were higher for the applications of $225 \mathrm{lb} /$ acre $\mathrm{N}(51,865$ and 49,335 lb/acre, respectively) and $280 \mathrm{lb} /$ acre $\mathrm{N}(54,564$ and 52,219 lb/acre, respectively) compared with the application of $170 \mathrm{lb} /$ acre $\mathrm{N}(47,929$ and 43,710 lb/acre, respectively). In Georgia, there were no significant interactions between production season and fertilizer $\mathrm{N}$ rates. In addition, there were no significant main effects of season or fertilizer $\mathrm{N}$ rate. Rainfall events accumulated 20.9 and 7.8 inches during the 2018 and 2019 growing seasons, respectively. Total and marketable yields averaged 37,290 and 33,355 $\mathrm{lb} /$ acre, respectively for the two growing seasons in Georgia. Cabbage cultivar had no interaction with fertilizer $\mathrm{N}$ rate in any location. 'Cheers' $(52,706 \mathrm{lb} / \mathrm{acre})$ had the highest total yield in Florida, and 'Ramada' (38,462 lb/acre) and 'Bronco' (39,379 lb/acre) had the highest total yields in Georgia. In conclusion, the application of $225 \mathrm{lb} /$ acre $\mathrm{N}$ was sufficient to sustain cabbage yields, but yields of the 170 - and 225-1b/acre $\mathrm{N}$ treatments were not different when rainfall events exceeded crop evapotranspiration.

$\mathrm{F}$ lorida and Georgia account for nearly 17,000 acres of cabbage (B. oleracea var. capitata) planted annually (Freeman et al., 2019; Wolfe

Received for publication 13 July 2020. Accepted for publication 8 Sept. 2020.

Published online 14 October 2020.

${ }^{1}$ Department of Horticulture, University of Georgia, 2360 Rainwater Road, Tifton, GA 31793

${ }^{2}$ Horticultural Science Department, University of Florida, 2550 Hull Road, Gainesville, FL 32611

A.L.B.R.d.S. is the corresponding author. E-mail: adasilva@uga.edu.

This is an open access article distributed under the CC BY-NC-ND license (https://creativecommons.org/ licenses/by-nc-nd/4.0/).

https://doi.org/10.21273/HORTTECH04690-20 and Stubbs, 2018), representing 28\% of the 61,100 acres of cabbage planted in the United States in 2015 (U.S. gia is on bare ground (i.e., without Department of Agriculture, 2019). Most production in Florida and Geor- plastic mulch) and the sandy soils of the coastal plain. Many farms in Florida use subirrigation (i.e., seepage system), whereas Georgia growers primarily rely on center-pivot irrigation systems. Sandy soils, irrigation management, and frequent rainfall events in the southeastern United States can lead to leaching of soil nitrogen $(\mathrm{N})$ in cabbage fields (Hendricks and Shukla, 2011; Scholberg et al., 2013). As a result, Florida and Georgia cabbage growers apply $\mathrm{N}$ fertilizer rates higher than the recommendations as a tentative measure to ensure high yields, which increase the cost of production, create environmental concerns, and may not imply an increase in crop productivity.

Current cabbage $\mathrm{N}$ fertilizer recommendations for sandy soils in Florida and Georgia range from 150 to $225 \mathrm{lb} /$ acre $\mathrm{N}$, split into three or more applications (Granberry et al., 2017; Liu et al., 2019). For claytextured soils, a fertilizer rate of 143 $\mathrm{lb} /$ acre $\mathrm{N}$ has been reported to optimize cabbage yield (Khan et al., 2002); however, maximum cabbage yields in sandy soils are reported at a fertilizer rate of $255 \mathrm{lb} /$ acre $\mathrm{N}$, suggesting that the recommended rate of $170 \mathrm{lb} /$ acre $\mathrm{N}$ is inadequate due to risks of $\mathrm{N}$ losses over rainy periods (Van Eerd et al., 2017). Recent studies conducted in sandy soils of northeast Florida reported an increase in cabbage yield with fertilization rates between 356 and $510 \mathrm{lb} /$ acre $\mathrm{N}$, when cabbage was grown at high planting density $(31,364$ plant/ acre) in plastic mulch with drip irrigation (Barrett et al., 2018). In contrast, prior research demonstrated that an increase in fertilizer rates from 135 to $270 \mathrm{lb} /$ acre $\mathrm{N}$ could be associated with decreased head quality and reduced cabbage marketable yield (Peck, 1981). Overall, the results of $\mathrm{N}$ fertilizer studies have been shown to vary widely according to production system, weather conditions, and soil characteristics.

\begin{tabular}{llll}
\hline $\begin{array}{l}\text { Units } \\
\text { To convert U.S. to SI, } \\
\text { multiply by }\end{array}$ & U.S. unit & SI unit & $\begin{array}{l}\text { To convert SI to U.S., } \\
\text { multiply by }\end{array}$ \\
\hline 0.4047 & $\mathrm{acre}(\mathrm{s})$ & $\mathrm{ha}$ & 2.4711 \\
0.3048 & $\mathrm{ft}$ & $\mathrm{m}$ & 3.2808 \\
2.54 & inch $(\mathrm{es})$ & $\mathrm{cm}$ & 0.3937 \\
0.4536 & $\mathrm{lb}$ & $\mathrm{kg}$ & 2.2046 \\
1.1209 & $\mathrm{lb} / \mathrm{acre}$ & $\mathrm{kg} \cdot \mathrm{ha}^{-1}$ & 0.8922 \\
$\left({ }^{\circ} \mathrm{F}-32\right) \div 1.8$ & ${ }^{\circ} \mathrm{F}$ & ${ }^{\circ} \mathrm{C}$ & $\left({ }^{\circ} \mathrm{C} \times 1.8\right)+32$
\end{tabular}


Although recent trials on highdensity plasticulture-grown cabbage in Florida suggest increased $\mathrm{N}$ fertilization rates are required for optimum yields, relatively little new information is available for cabbage grown using bare ground production and irrigation systems more typical to Florida and Georgia growers. Furthermore, advanced breeding techniques have been shown to increase the $\mathrm{N}$ uptake efficiency of new cabbage cultivars (Dewi et al., 2010) used in both states. Therefore, an update on $\mathrm{N}$ fertilizer rates recommendation for Florida and Georgia cabbage production would benefit growers in the region. The objective of this study was to evaluate the effect of three fertilizer $\mathrm{N}$ rates on yield and head quality for common cabbage cultivars used by Florida and Georgia growers during four cabbage growing seasons.

\section{Material and methods}

Field experiments were conducted at the University of Florida, Hastings Agricultural Extension Center in Hastings (lat. $29.6946^{\circ} \mathrm{N}$, long. $81.4426^{\circ} \mathrm{W}$ ) in 2016 and 2017 , and at the University of Georgia, Horticultural Research Farm in Tifton (lat. $31.4727^{\circ} \mathrm{N}$, long. $83.5306^{\circ} \mathrm{W}$ ) in 2018 and 2019. Site characterization and crop management details with respective dates are described in Table 1.

Studied locations are in a humid subtropical climate region, characterized by high air temperatures with heavy rainfall events in the summer and cool dry periods in the winter (Köppen, 1931). During cabbage development, rainfall, maximum and minimum air temperature, and reference evapotranspiration were measured every $15 \mathrm{~min}$ and aggregated to hourly using an automated weather station from the Florida Automated Weather Network [FAWN, Hastings Station, Hastings (University of Florida, 2019)] and Georgia Automated Environmental Monitoring Network [University of Georgia Weather Network, Tifton Station, Tifton (University of Georgia, 2019)]. Growing degree days (GDD), after cabbage transplanting, were calculated by averaging the daily maximum and minimum air temperature minus the base air temperature of $50{ }^{\circ} \mathrm{F}$ (Isenberg et al., 1975), and crop evapotranspiration was calculated by multiplying the reference evapotranspiration and cabbage crop coefficients (Allen et al., 1998).

EXPERIMENTAL DESIGN AND CROP MANAGEMENT. A randomized complete block design $(r=4)$ was used with a split-plot design of fertilizer $\mathrm{N}$ rate $(\mathrm{n}=3)$ and cabbage cultivar $(\mathrm{n}=$ $6)$. Fertilizer $\mathrm{N}$ rate treatments were assigned as the main plot and cabbage cultivar as the sub-plot. In both studied locations, all fertilizer treatments received $45 \mathrm{lb} /$ acre $\mathrm{N}$ at pre-plant [10N-4.4P-8.3K (Super Rainbow; Agrium U.S., Loveland, CO)] and 42,60 , and $78 \mathrm{lb} /$ acre $\mathrm{N}$ [calcium nitrate, $15.5 \mathrm{~N}-0 \mathrm{P}-0 \mathrm{~K}$ (YaraLiva; Yara North America, Tampa, FL)] in three subsequent applications for a total of 170,225 , and $280 \mathrm{lb} /$ acre $\mathrm{N}$, respectively. Posttransplant fertilizer was applied in bands on $\approx 8$ inches from the planted row in both locations. Fertilizer application dates for each year and location are presented in Table 1 .

Cabbage cultivars were Bravo (HM Clause, Davis, CA), Cheers (American Takii, Salinas, CA), Capture, Bronco, Ramada, and Bruno (Bejo Seeds, Oceano, CA). Selected cultivars were green cabbage intended for fresh market. In both studied locations, cabbage seeds were planted into 200-cell trays filled with soilless media (Pro-Mix BX; Premier Tech, Rivieredu-Loup, QC, Canada); plants were grown in a greenhouse for 5 weeks and then transplanted onto raised bare ground beds. Information on transplanting date, bed spacing, bed height, rows within beds, row spacing within a bed, plant in-row spacing, and plant population are presented in Table 1 .

In the Florida site, sub-plots (i.e., cabbage cultivar treatments) were composed of 30 cabbage plants (20 ft long), whereas sub-plots (i.e., cabbage cultivar treatments) in the Georgia site were composed of 40 cabbage plants (20 ft long). Adjacent plots within a bed were separated by a 5 - $\mathrm{ft}$ buffer in both locations, consequently, main plots (i.e., fertilizer $\mathrm{N}$ rate treatments) were $150 \mathrm{ft}$ long in both locations.

During all cabbage seasons, irrigation water was applied using seepage irrigation in the Florida site, and sprinkler irrigation in the Georgia site. Seepage irrigation consists of the management of water table level so capillarity can supply water to the cabbage root zone, and the water table level was managed between 16 and 24 inches below the soil surface as recommended by da Silva et al. (2018). Sprinkler irrigation supplied water overhead and irrigation events followed the cabbage crop evapotranspiration. In the case of rainfall events, irrigation water was seceded and returned after $4 \mathrm{~d}$ in both locations. Crop management related to pest management followed the University of Florida and University of Georgia recommendations (Dutta et al., 2018; Zotarelli et al., 2019).

Cabbage harvesting. In both locations (i.e., Florida and Georgia), cabbage heads were harvested twice in each season, except in the 2016 study in Florida when a single harvest was performed (Table 1 ). The first harvest was carried out when $50 \%$ of heads reached marketable size. A second harvest occurred when remaining heads in the field were considered marketable. Cabbage heads were harvested by cutting the stem at the soil surface and removing wrapper leaves. Heads were classified as marketable for fresh market when trimmed head weight was more than $2 \mathrm{lb}$ and unmarketable for heads weighing less than $2 \mathrm{lb}$. Total yield was calculated as marketable and unmarketable trimmed heads. In addition, measurements of cabbage head equatorial and polar diameter, core height, and core width were recorded from five marketable cabbage heads randomly selected in the first harvest of each plot.

Statistical analysis. Statistical analyses were performed using linear mixed techniques as implemented in SAS PROC GLIMMIX (SAS/STAT 14.2; SAS Institute, Cary, NC). Total, marketable, and unmarketable yield, as well as, head polar diameter, head equatorial diameter, core height, and core width were analyzed separately within each location in which fertilizer treatments (i.e., 170, 225 , and $280 \mathrm{lb} /$ acre $\mathrm{N}$ ), cabbage cultivar (i.e., Bravo, Cheers, Capture, Bronco, Ramada, and Bruno), year (2016 and 2017 in Florida, 2018 and 2019 in Georgia), and their interactions were treated as fixed effects. Block was treated as a random effect, whereas year was treated as a repeated measurement. The covariance structure used according to the smallest Akaike's information criterion was the heterogeneous compound 
Table 1. Characterization of soil type, bed spacing, bed height, rows within a bed, row spacing within bed, plant in-row spacing, plant population, and irrigation systems for the Florida and Georgia experimental locations. Description of crop management practices, such as transplanting date, fertilizer nitrogen $(\mathrm{N})$ applications, harvesting date, and accumulated growing degree days for the 2016 and 2017 cabbage growing seasons in Florida and 2018 and 2019 cabbage growing seasons in Georgia.

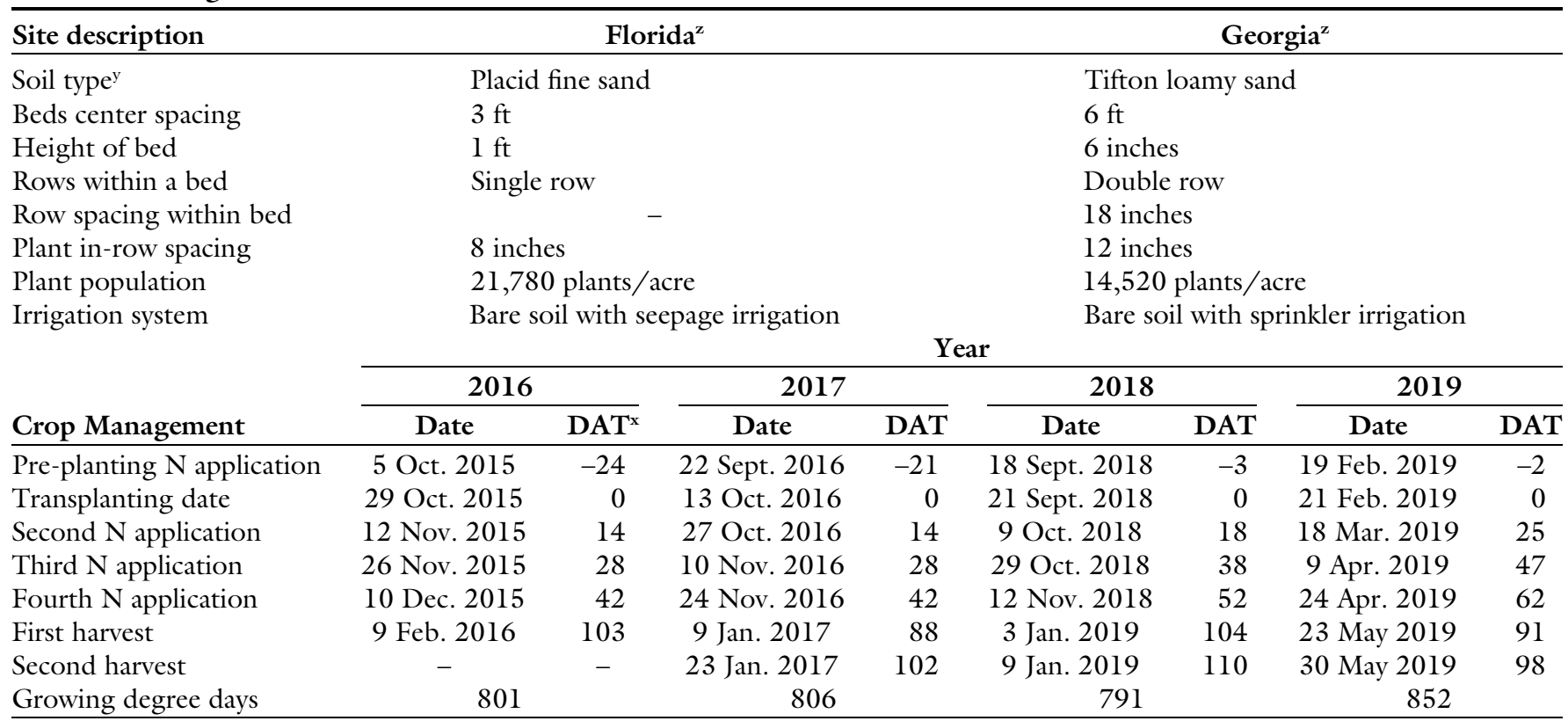

${ }^{\mathrm{z}} \mathrm{l} \mathrm{ft}=0.3048 \mathrm{~m}, \mathrm{l}$ inch $=2.54 \mathrm{~cm}, \mathrm{l}$ plant $/$ acre $=2.471 \mathrm{l}$ plants $/ \mathrm{ha}$.

${ }^{y}$ Data retrieved from U.S. Department of Agriculture (1983).

${ }^{\mathrm{x}}$ Days after transplanting.

symmetry. Least square means comparisons were performed using the Tukey-Kramer adjusted at probability value of 0.05 , and means were portioned using the slice command in SAS.

\section{Results}

WeATHer CONDitions. In Florida, the average minimum and maximum air temperatures were 54 and 74 ${ }^{\circ} \mathrm{F}$ in 2016 and 52 and $77^{\circ} \mathrm{F}$ in 2017 , respectively. Average air temperatures were similar for both growing seasons. However, low air temperatures between 70 and $90 \mathrm{~d}$ after transplant (DAT) in 2016 reduced the GDD accumulation during this period (Fig. 1), which delayed cabbage growth, resulting in a single harvest during that growing season. In 2018 , cabbage in Georgia was grown during the fall, which is warm early in the season but cold late in the season (Fig. 1). In 2019, cabbage was grown during the spring in Georgia, which is cold earlier in the season and warmer late in the season (Fig. 1). Average minimum and maximum air temperatures were 54 and $72{ }^{\circ} \mathrm{F}$ in 2018 , and 56 and $77^{\circ} \mathrm{F}$ in 2019 , respectively. Cabbage in 2018 was harvested 13 and $12 \mathrm{~d}$ later for the first and second harvests compared with 2019, respectively (Table 1). Delays in harvesting were due to reduced GDD accumulation that slowed cabbage growth later in the season in 2018 (Fig. 1). The GDD accumulation in the growing season of 2019 was slow early season but hastened later as expected.

Rainfall events in 2016 totaled 10.5 inches and were evenly distributed throughout the production season in Florida. Rainfall accumulation in 2016 was higher than the accumulated crop evapotranspiration of 6.3 inches for the same period. However, there were two particular events in 2016, at 9 DAT (2.3 inches) and 89 DAT (2.4 inches), that accounted for $45 \%$ of the total rainfall in that year (Fig. 1). The Florida growing season of 2017 was drier than 2016 and accumulated 2.1 inches of rain. Accumulated crop evapotranspiration for the cabbage season of 2017 was 5.8 inches and irrigation events were the primary source of water. Particularly, most rainfall events in 2017 occurred near the end of the production season (Fig. 1). In Georgia, total rainfall events were 20.9 and 7.8 inches for the 2018 and 2019 growing seasons, respectively. Both years, still, required irrigation events to supply the accumulated crop evapotranspiration of 5.8 and 11.2 inches in 2018 and 2019, respectively. Particularly, rainfall events occurred relatively evenly during the entire cabbage season in 2018, but tended to occur before 65 DAT in 2019 (Fig. 1), when fertilizer $\mathrm{N}$ treatments were being applied.

Cabbage yield. There was no interaction among cultivar, fertilizer $\mathrm{N}$ rate, and year for cabbage total, marketable, and unmarketable yield in any location. However, total and marketable yields were significantly affected by the main effect of cultivar in both locations (Table 2). Unmarketable yields were significantly affected by cultivar in Georgia, but not in Florida (Table 2). In Florida, there was a significant interaction between fertilizer $\mathrm{N}$ rate and year on total and marketable yields (Table 3 ), which was not measured in Georgia. The main effect of year significantly affected unmarketable yield in both Florida and Georgia (Table 4).

In Florida, cabbage total yield was $10 \%$ higher on average for 'Cheers' than all other cultivars (Table 2). Similar results were measured for marketable yield, in which 'Cheers' had the highest marketable yield with 49,062 


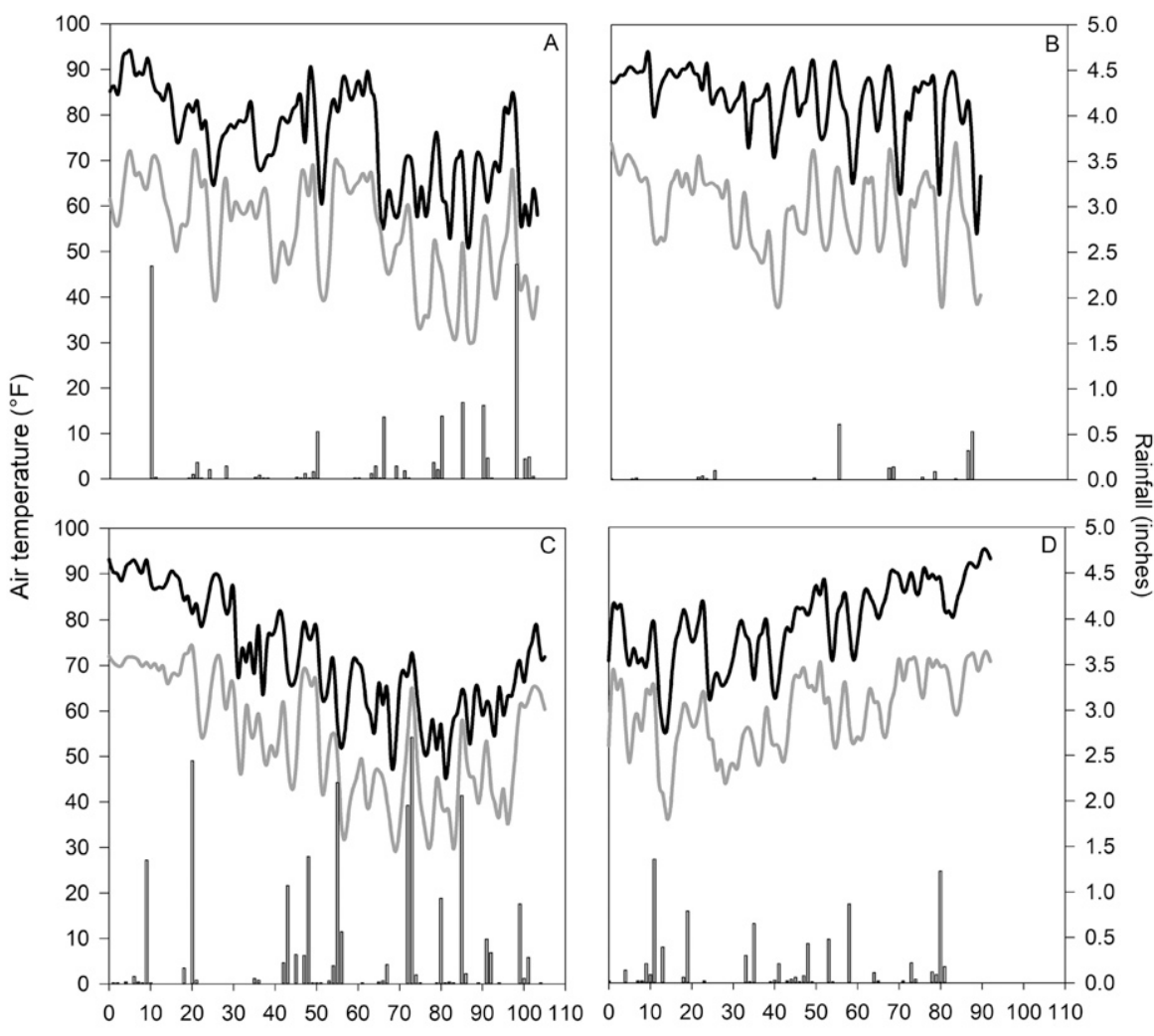

Days after transplanting

Maximum air temperature $\longrightarrow$ Minimum air temperature $\square$ Rainfall

Fig. 1. Maximum and minimum air temperature and rainfall events for the Florida cabbage seasons of 2016 (A) and 2017 (B) and Georgia cabbage seasons of 2018 (C) and 2019 (D). Data recorded at 15-min intervals and aggregate to hourly, retrieved from the Florida Automated Weather Network at Hastings, FL

(University of Florida, 2019), and the Georgia Automated Environmental

Monitoring Network at Tifton, GA (University of Georgia, 2019); $\left({ }^{\circ} \mathrm{F}-32\right) \div$ $1.8={ }^{\circ} \mathrm{C}, 1$ inch $=2.54 \mathrm{~cm}$.

Table 2. Main effect of cabbage cultivar on total, marketable, and unmarketable yield in Florida and Georgia.

\begin{tabular}{lccc}
\hline & Total yield & Marketable yield & Unmarketable yield \\
\cline { 2 - 4 } Cultivar & \multicolumn{3}{c}{$(\mathbf{b} / \text { acre })^{\mathbf{z}}$} \\
\hline Cheers & $52,706 \mathrm{a}^{\mathrm{y}}$ & Florida \\
Ramada & $47,982 \mathrm{~b}$ & $49,062 \mathrm{a}$ & 3,644 \\
Bruno & $47,917 \mathrm{~b}$ & $42,905 \mathrm{~b}$ & 5,077 \\
Capture & $47,377 \mathrm{~b}$ & $42,531 \mathrm{~b}$ & 5,386 \\
Bronco & $47,354 \mathrm{~b}$ & $41,576 \mathrm{~b}$ & 5,801 \\
Bravo & $47,192 \mathrm{~b}$ & $42,125 \mathrm{~b}$ & 5,229 \\
Pvalue & 0.003 & $42,917 \mathrm{~b}$ & 4,274 \\
& & $<0.001$ & 0.096 \\
Cheers & $37,076 \mathrm{ab}$ & Georgia & $3,255 \mathrm{~b}$ \\
Ramada & $38,462 \mathrm{a}$ & $33,821 \mathrm{ab}$ & $3,455 \mathrm{ab}$ \\
Bruno & $37,198 \mathrm{ab}$ & $34,951 \mathrm{a}$ & $4,755 \mathrm{ab}$ \\
Capture & $34,164 \mathrm{~b}$ & $32,443 \mathrm{ab}$ & $5,117 \mathrm{a}$ \\
Bronco & $39,379 \mathrm{a}$ & $29,046 \mathrm{~b}$ & $3,699 \mathrm{ab}$ \\
Bravo & $37,461 \mathrm{ab}$ & $35,680 \mathrm{a}$ & $3,271 \mathrm{~b}$ \\
$P$ value & 0.027 & $34,190 \mathrm{a}$ & 0.010 \\
\hline
\end{tabular}

${ }^{\mathrm{z}} \mathrm{l} \mathrm{lb} / \mathrm{acre}=1.1209 \mathrm{~kg} \cdot \mathrm{ha}^{-1}$.

y Values followed by similar letters indicate no significant differences $(P \leq 0.05)$ among cultivar within each location according to Tukey-Kramer adjustment. $\mathrm{lb} / \mathrm{acre}$ and there was no significant difference among the other cultivars evaluated. Unmarketable cabbage yields were not significantly different among cultivars in Florida (Table 2). In Georgia, cabbage total yield was the highest for 'Bronco' and 'Ramada' with $39,379 \mathrm{lb} /$ acre and $38,462 \mathrm{lb} /$ acre, respectively; however, they were not significantly different from 'Bravo', 'Bruno', and 'Cheers' (Table 2). Marketable yields were the highest for 'Bronco', 'Ramada', and 'Bravo' with $35,680 \mathrm{lb} / \mathrm{acre}, 34,95 \mathrm{l} \mathrm{lb} / \mathrm{acre}$, and $34,190 \mathrm{lb} /$ acre, while unmarketable yields were the highest for 'Capture' and lowest for 'Ramada' and 'Bronco' (Table 2).

Regardless of cultivar, cabbage total yields increased when fertilizer rates exceeded $170 \mathrm{lb} /$ acre $\mathrm{N}$ in 2017, but not in 2016 in Florida (Table 3). In 2017, cabbage total yield was significantly greater in the $280-\mathrm{lb} /$ acre $\mathrm{N}$ fertilizer rate $(54,564$ $\mathrm{lb} / \mathrm{acre}$ ) compared with the 170-lb/ acre $\mathrm{N}$ fertilizer rate $(47,929 \mathrm{lb} /$ acre). Total yield in the $225-\mathrm{lb} /$ acre $\mathrm{N}$ fertilizer rate was not significantly different from either the 170 - or 280 $\mathrm{lb} /$ acre $\mathrm{N}$ fertilizer rates in 2017 (Table 3). In 2017, marketable yields were significantly higher in the 225and $280-\mathrm{lb} /$ acre $\mathrm{N}$ fertilizer rates compared with the 170-lb/acre $\mathrm{N}$ fertilizer rate. This result indicates that in rainy years the application of $225 \mathrm{lb} /$ acre $\mathrm{N}$ was sufficient to sustain cabbage marketable yield.

In Georgia, where there were no significant differences among fertilizer $\mathrm{N}$ rates or the interactions between year and fertilizer $\mathrm{N}$ rate, cabbage total and marketable yields across all treatments averaged 37,290 and $33,355 \mathrm{lb} /$ acre, respectively. Unmarketable yields in Georgia were significantly greater in the 2019 season compared with 2018 (Table 4).

Head Quality. Similar to yield, there was no interaction among cultivar, fertilizer $\mathrm{N}$ rate, and year for any cabbage head quality parameter in any location. Cabbage cultivar significantly affected head polar and equatorial diameters, and core height in Florida, and head equatorial diameter and core height in Georgia (Table 5). Fertilizer $\mathrm{N}$ rate significantly interacted with year for head polar diameter in Florida (Table 3), whereas the main effect of year was significantly different for head equatorial diameter 
Table 3. Effect of the interaction between fertilizer nitrogen $(\mathrm{N})$ rate and year on total yield, marketable yield, and head polar diameter for cabbage grown in Florida.

\begin{tabular}{|c|c|c|}
\hline \multirow[b]{2}{*}{ Fertilizer $\mathrm{N}$ rate $(\mathrm{lb} / \mathrm{acre})^{\mathrm{z}}$} & \multicolumn{2}{|c|}{ Yr } \\
\hline & 2016 & 2017 \\
\hline & \multicolumn{2}{|c|}{ Total yield (lb/acre) } \\
\hline 170 & $45,434 b^{y} A^{x}$ & 47,929 a B \\
\hline 225 & $46,587 \mathrm{~b} A$ & 51,865 a $A B$ \\
\hline \multirow[t]{2}{*}{280} & 44,152 b A & 54,564 a $\mathrm{A}$ \\
\hline & \multicolumn{2}{|c|}{ Marketable yield (lb/acre) } \\
\hline 170 & 38,705 a A & 43,710 a $\mathrm{B}$ \\
\hline 225 & 39,935 b A & 49,335 a $\mathrm{A}$ \\
\hline \multirow[t]{2}{*}{280} & 37,214 b A & 52,219 a A \\
\hline & \multicolumn{2}{|c|}{ Head polar diam (inches) ${ }^{\mathrm{z}}$} \\
\hline 170 & 7.3 a $A$ & 5.7 b B \\
\hline 225 & $7.3 \mathrm{a} \mathrm{A}$ & $5.9 \mathrm{~b} \mathrm{AB}$ \\
\hline 280 & $7.2 \mathrm{a} A$ & $6.0 \mathrm{~b} \mathrm{~A}$ \\
\hline
\end{tabular}

${ }^{\mathrm{z}} 1 \mathrm{lb} /$ acre $=1.1209 \mathrm{~kg} \cdot \mathrm{ha}^{-1}, \mathrm{l}$ inch $=2.54 \mathrm{~cm}$.

${ }^{y}$ Values followed by the same lowercase letter within fertilizer $\mathrm{N}$ rate (row) indicates no significant differences $(P \leq$ 0.05 ) among year (column) according to Tukey-Kramer adjustment.

${ }^{x}$ Values followed by the same uppercase letter within year (column) indicates no significant differences $(P \leq 0.05)$ among fertilizer $\mathrm{N}$ rate (row) according to Tukey-Kramer adjustment.

Table 4. Main effect of year on cabbage unmarketable yield, head equatorial diameter, and core width in Florida and Georgia.

\begin{tabular}{|c|c|c|c|}
\hline \multirow[b]{2}{*}{ Yr } & Unmarketable yield & Head equatorial diam & Core width \\
\hline & $(\mathrm{lb} / \mathrm{acre})^{\mathrm{z}}$ & \multicolumn{2}{|l|}{${\text { (inches })^{\mathrm{z}}}$} \\
\hline & \multicolumn{3}{|c|}{ Florida } \\
\hline 2016 & $6,773 \mathrm{a}^{\mathrm{y}}$ & $7.4 \mathrm{a}$ & $1.8 \mathrm{a}$ \\
\hline \multirow[t]{2}{*}{2017} & $3,031 \mathrm{~b}$ & $6.0 \mathrm{~b}$ & $1.4 \mathrm{~b}$ \\
\hline & \multicolumn{3}{|c|}{ Georgia } \\
\hline 2018 & $3,519 \mathrm{~b}$ & $5.6 \mathrm{~b}$ & $1.2 \mathrm{~b}$ \\
\hline 2019 & $4,332 \mathrm{a}$ & $6.1 \mathrm{a}$ & $1.8 \mathrm{a}$ \\
\hline
\end{tabular}

${ }^{\mathrm{z}} 1 \mathrm{lb} /$ acre $=1.1209 \mathrm{~kg} \cdot \mathrm{ha}^{-1}, \mathrm{l}$ inch $=2.54 \mathrm{~cm}$.

'Values followed by similar letters indicate no significant differences $(P \leq 0.05)$ among cultivar within each location according to Tukey-Kramer adjustment.

Table 5. Main effect of cabbage cultivar on head polar and equatorial diameter and core height and width in Florida and Georgia.

\begin{tabular}{lcccc}
\hline & Head polar diam & Head equatorial diam & Core ht & Core width \\
\cline { 2 - 5 } Cultivar & \multicolumn{5}{c}{ (inches) } \\
Cheers & $6.7 \mathrm{ab}^{\mathrm{y}}$ & Florida & \\
Ramada & $6.3 \mathrm{~d}$ & $7.0 \mathrm{a}$ & $3.1 \mathrm{ab}$ & 1.5 \\
Bruno & $6.6 \mathrm{bc}$ & $6.9 \mathrm{a}$ & $3.2 \mathrm{a}$ & 1.6 \\
Capture & $6.5 \mathrm{c}$ & $6.5 \mathrm{bc}$ & $3.0 \mathrm{ab}$ & 1.6 \\
Bronco & $6.8 \mathrm{a}$ & $6.4 \mathrm{c}$ & $2.9 \mathrm{~b}$ & 1.7 \\
Bravo & $6.5 \mathrm{c}$ & $6.5 \mathrm{bc}$ & $3.0 \mathrm{ab}$ & 1.6 \\
Pvalue & $<0.001$ & $6.8 \mathrm{ab}$ & $3.1 \mathrm{ab}$ & 1.5 \\
& & $<0.001$ & $<0.001$ & 0.526 \\
Cheers & 6.3 & $\mathrm{Georgia}$ & & \\
Ramada & 6.2 & $5.9 \mathrm{ab}$ & $2.3 \mathrm{ab}$ & 1.5 \\
Bruno & 5.9 & $5.7 \mathrm{bc}$ & $2.7 \mathrm{a}$ & 1.4 \\
Capture & 6.0 & $6.2 \mathrm{ab}$ & $2.6 \mathrm{ab}$ & 1.5 \\
Bronco & 6.2 & $5.2 \mathrm{c}$ & $2.1 \mathrm{~b}$ & 1.3 \\
Bravo & 6.3 & $6.4 \mathrm{a}$ & $2.6 \mathrm{ab}$ & 1.6 \\
Pvalue & 0.120 & $5.9 \mathrm{~b}$ & $2.7 \mathrm{a}$ & 1.4 \\
\hline
\end{tabular}

${ }^{\mathrm{z}} 1$ inch $=2.54 \mathrm{~cm}$

${ }^{y}$ Values followed by similar letters indicate no significant differences $(P \leq 0.05)$ among cultivar within each location according to Tukey-Kramer adjustment. and core width in both Florida and Georgia (Table 4).

Head polar diameters in Florida were the highest for cultivars Bronco and Cheers, which averaged 6.8 and 6.7 inches, respectively. The cultivar Ramada had the lowest head polar diameter in Florida at 6.3 inches. Head equatorial diameter was the largest for 'Cheers' (7.0 inches) and 'Ramada' (6.9 inches), which were significantly greater than 'Bronco', 'Bruno', and 'Capture'. In Florida, cabbage core height was the highest for 'Ramada' (3.2 inches) and the lowest for 'Capture' (2.9 inches), whereas core width was not significantly different among cultivars and averaged 1.6 inches (Table 5).

In Georgia, head polar diameter averaged 6.2 inches and was not significantly affected by cultivar $(\mathrm{Ta}-$ ble 5$)$. The cultivar Bronco had the highest head equatorial diameter $(6.4$ inches) but this was not significantly different from 'Cheers' and 'Bruno'. The cultivar Capture had the lowest head equatorial diameters (5.2 inches). Core height was significantly greater in 'Ramada' and 'Bravo' (2.7 inches each) compared with 'Capture' (2.1 inches). Cabbage core width was not significantly affected by cultivar in Georgia and averaged 1.5 inches (Table 5).

For the interaction of fertilizer $\mathrm{N}$ rate and year in Florida (Table 3), there was no impact of fertilizer $\mathrm{N}$ rate on head polar diameter in 2016. However, in 2017, cabbage grown with $280 \mathrm{lb} /$ acre $\mathrm{N}$ had significantly greater head polar diameters than those grown with $170 \mathrm{lb} /$ acre $\mathrm{N}$. Cabbage grown with $225 \mathrm{lb} /$ acre N had a head polar diameter that was not different from cabbage grown with either 170 or $280 \mathrm{lb} /$ acre $\mathrm{N}$.

\section{Discussion}

Weather conditions can significantly impact cabbage growth in the southeastern United States (Paranhos et al., 2016). Air temperatures affect growth and days until harvest (Barrett et al., 2015), and rainfall events affect the soil $\mathrm{N}$ availability that may influence cabbage yields (Janes, 1950).

Optimal air temperatures for cabbage crop development are between 59 and $70{ }^{\circ} \mathrm{F}$ (Criddle et al., 1997; Hara and Sonoda, 1982), whereas cabbage yields are maximized at air temperatures of $64^{\circ} \mathrm{F}$ (Paranhos et al., 2016). 
Air temperature patterns among the four seasons studied were similar and fell within the optimal ranges for cabbage growth. In general, air temperatures were higher earlier in the season, but decreased later. The exception was in the Georgia growing season of 2019 , when cabbage was grown during the spring and air temperatures were lower early season and increased during crop development. In spring-grown cabbage, low air temperatures early in the season lengthen the vegetative stage and the high air temperatures late season reduce the period for head formation (Mckeown et al., 2010). Consequently, the GDD accumulated quicker and harvesting was $14 \mathrm{~d}$ earlier for cabbage grown during the spring compared with fall in Georgia.

After rainfall events, granular $\mathrm{N}$ fertilizer is solubilized in the soil, allowing for plant uptake; however, the rapid soil water movement of the sandy soils in Florida and Georgia leaches soluble $\mathrm{N}$ below the cabbage root zone (Scholberg et al., 2013). Therefore, although air temperature plays a key role in cabbage crop development, rainfall events affect cabbage yields due to their impact on soil $\mathrm{N}$ availability (Sanchez et al., 1994; Thomas et al., 1970). In the present study, when rainfall accumulation was similar or higher than the crop evapotranspiration (i.e., 2016 in Florida, 2018 in Georgia) or primarily occurred during the timing of fertilizer $\mathrm{N}$ applications (i.e., 2019 in Georgia), there were no significant effects of fertilizer $\mathrm{N}$ rates on cabbage yield. The absence of significant differences among fertilizer $\mathrm{N}$ rates in rainy periods after fertilizer application may be due to the movement of soil $\mathrm{N}$ below the root zone, which has been previously reported for cabbage production areas with sandy soils (Everaarts and Booi, 2000; Janes, 1950; Smith et al., 2016; Van Eerd et al., 2017). In contrast, the dry growing season in 2017 in Florida allowed for cabbage total and marketable yield to effectively increase under the fertilizer rates of 225 and $280 \mathrm{lb} /$ acre $\mathrm{N}$ compared with the application of $170 \mathrm{lb} /$ acre $\mathrm{N}$. In this season, irrigation was the primary source of water for the crop; thereby, the effects of fertilizer applications were more pronounced during the 2017 season because irrigation was managed to reduce soil $\mathrm{N}$ leaching (Barrett et al.,
2018). This result indicated that cabbage yields may be limited with 170 $\mathrm{lb} /$ acre $\mathrm{N}$, but not with $225 \mathrm{lb} / \mathrm{acre}$ $\mathrm{N}$, which was the fertilizer $\mathrm{N}$ rate required to sustain maximum yields. These results are corroborated with other studies reporting that the application of fertilizer rate of $170 \mathrm{lb} /$ acre $\mathrm{N}$ can be increased to $225 \mathrm{lb} /$ acre $\mathrm{N}$ in cabbage production areas under sandy soils (Bakker et al., 2009; McKeown et al., 2010; Van Eerd et al., 2017; Zebarth et al., 1991).

Overall, our results suggest that current recommendations for fertilizer rate applications of $170 \mathrm{lb} / \mathrm{acre}$ $\mathrm{N}$ would not produce optimum cabbage yields in most growing seasons. Nevertheless, the grower practice of applying $280 \mathrm{lb} /$ acre $\mathrm{N}$ could also be reduced to a fertilizer rate of $225 \mathrm{lb} /$ acre $\mathrm{N}$, regardless of cabbage cultivar.

\section{Conclusions}

Cabbage fertilizer applications above the recommended rates of 150 to $225 \mathrm{lb} /$ acre N in Florida and Georgia are commonly used as a way to ensure high yields under growing conditions that facilitate soil $\mathrm{N}$ leaching. The present study evaluated the effect of three fertilizer rates (i.e., 170,225 , and $280 \mathrm{lb} /$ acre $\mathrm{N}$ ) on yield and head quality for common cabbage cultivars used by Florida and Georgia growers during four cabbage growing seasons. Overall, there was no increase in cabbage yield with increased fertilizer $\mathrm{N}$ rates in years when rainfall accumulation was similar or higher than the cabbage crop evapotranspiration. The fertilizer rate of $225 \mathrm{lb} /$ acre $\mathrm{N}$ was sufficient to maintain cabbage yield in a dry year, indicating that cabbage yields may be maximized under this $\mathrm{N}$ rate in sandy soils of the southeastern United States. Future studies should focus on investigating the timing of fertilizer application on cabbage production, which would help to account for the weather variability on the interaction soil $\mathrm{N}$ availability and crop development.

\section{Literature cited}

Allen, R.G., L.S. Pereira, D. Raes, and M. Smith. 1998. Crop evapotranspiration under standard conditions, p. 87-156. In: Crop evapotranspiration (Guidelines for computing crop water requirements). FAO Irr. Drain. Paper 56.
Bakker, C.J., C.J. Swanton, and A.W. McKeown. 2009. Broccoli growth in response to increasing rates of pre-plant nitrogen. I. Yield and quality. Can. J. Plant Sci. 89:527-537.

Barrett, C.E., L. Zotarelli, L.G. Paranhos, B.S. Taylor, P.J. Dittmar, C.W. Fraisse, and J. VanSickle. 2015. Optimum planting configuration for high population plasticulture grown cabbage. HortScience 50:1472-1478.

Barrett, C.E., L. Zotarelli, L.G. Paranhos, B.S. Taylor, P.J. Dittmar, C.W. Fraisse, and J. VanSickle. 2018. Optimization of irrigation and $\mathrm{N}$-fertilizer strategies for cabbage plasticulture system. Scientia Hort. 234:323-334.

Criddle, R.S., B.N. Smith, and L.D. Hansen. 1997. A respiration based description of plant growth rate responses to temperature. Planta 201:441-445.

da Silva, A.L.B.R., H.T. Hashiguti, L. Zotarelli, K.W. Migliaccio, and M.D. Dukes. 2018. Soil water dynamics of shallow water table soils cultivated with potato crop. Vadose Zone J. 17:1-15.

Dewi, E.R., O. Nikus, and W.J. Horst. 2010. Genotypic differences in nitrogen efficiency of white cabbage (Brassica oleracea L.). Plant Soil 328:313-325.

Dutta, B., A. Sparks, and D. Riley. 2018. Vegetables, p. 309-498. In: M.D. Taylor (ed.). Georgia pest management handbook 2018. Univ. Georgia Coop. Ext. Serv. Spec. Bull. 28.

Everaarts, A.P. and R. Booi. 2000. The effect of nitrogen application on nitrogen utilization by white cabbage (Brassica olevacea var. capitata) and on nitrogen in the soil at harvest. J. Hort. Sci. Biotechnol. 75:705-712.

Freeman, J.H., P.J. Dittmar, and G.E. Vallad. 2019. Commercial vegetable production in Florida, p. 1-2. In: P.J. Dittmar (ed.). Vegetable production handbook of Florida 2019-2020. Univ. Florida IFAS Ext. CV292.

Granberry, D., W.T. Kelly, and G. Boyhan. 2017. Soil and fertilizer management, p. 8-12. In: T. Coolong (ed.). Commercial production and management of cabbage and leafy greens. Univ. Georgia Coop. Ext. Serv. Bull. 1181.

Hara, T. and Y. Sonoda. 1982. Cabbagehead development as affected by nitrogen and temperature. Soil Sci. Plant Nutr. 28:109-117.

Hendricks, G.S. and S. Shukla. 2011. Water and nitrogen management effects on water and nitrogen fluxes in Florida Flatwoods. J. Environ. Qual. 40:18441856. 
Isenberg, F.M.R., A. Pendergress, J.E. Carroll, L. Howell, and E.B. Oyer. 1975. The use of weight, density, heat units, and solar radiation to predict the maturity of cabbage for storage. J. Amer. Soc. Hort. Sci. 100:313-316.

Janes, B.E. 1950. The effect of irrigation, nitrogen level and season on the composition of cabbage. Plant Physiol. 25:441452 .

Khan, R., S. Ahmed, S. Khan, F. Ahmed, M. Zaman, and B.A. Khan. 2002. Effect of different levels of nitrogen, phosphorus and potassium on the growth and yield of cabbage. Asian J. Plant Sci. 1:548-549.

Köppen, W. 1931. Grundriss der Klimakunde. Walter de Gruyter, Berlin, Germany.

Liu, G.D., E.H. Simonne, K.T. Morgan, G.J. Jochmuth, S. Agehara, and R. Mylavarapu. 2019. Fertilizer management for vegetable production in Florida, p. 3-9. In: P.J. Dittmar (ed.). Vegetable production handbook of Florida 2019-2020. Univ. Florida IFAS Ext. CV292.

McKeown, A.W., S.M. Westerveld, and C.J. Bakker. 2010. Nitrogen and water requirements of fertigated cabbage in Ontario. Can. J. Plant Sci. 90:101-109.
Paranhos, L.G., C.E. Barrett, L. Zotarelli, R. Darnell, K. Migliaccio, and T. Borisova. 2016. Planting date and in-row plant spacing effects on growth and yield of cabbage under plastic mulch. Scientia Hort. 202:49-56.

Peck, N.H. 1981. Cabbage plant responses to nitrogen fertilization. Agron. J. 73:679-684.

Sanchez, C.A., R.L. Roth, and B.R. Gardner. 1994. Irrigation and nitrogen management for sprinkler-irrigated cabbage on sand. J. Amer. Soc. Hort. Sci. 119:427-433.

Scholberg, J.M.S., L. Zotarelli, M.D. Dukes, M. Ozores-Hampton, and G.D. Liu. 2013. Enhancing fertilizer efficiency in high input cropping systems in Florida. Sustain. Agr. Res. 12:143-174.

Smith, R., M. Cahn, T. Hartz, P. Love, and B. Farrara. 2016. Nitrogen dynamics of cole crop production: Implications for fertility management and environmental protection. HortScience 51:1586-1591.

Thomas, J.R., L.N. Namken, and R.G. Brown. 1970. Yield of cabbage in relation to nitrogen and water supply. J. Amer. Soc. Hort. Sci. 95:732-735.

University of Florida. 2019. Hastings, Florida climate data. 1 Sept. 2019. <https:// fawn.ifas.ufl.edu/data/reports/>.
University of Georgia. 2019. Tifton, Georgia climate data. 1 Sept. 2019. <http://www. georgiaweather.net/?content $=$ calculator\& variable $=\mathrm{CC} \&$ site $=$ TIFTON $>$.

U.S. Department of Agriculture. 1983. Soil survey. Web soil survey - Soil survey of Tift County, Georgia. 23 Aug. 2019. <https:// websoilsurvey.sc.egov.usda. gov/App/ WebSoilSurvey.aspx $>$.

U.S. Department of Agriculture. 2019. Census of agriculture. 3 Sept. 2020. <https://quickstats.nass.usda.gov>.

Van Eerd, L.L., J.J.D. Turnbull, C.J. Bakker, R.J. Vyn, A.W. McKeown, and W.M. Westerveld. 2017. Comparing soluble to controlled-release nitrogen fertilizers: Storage cabbage yield, profit margins, and $\mathrm{N}$ use efficiency. Can. J. Plant Sci. 98:815-829.

Wolfe, K.L. and K. Stubbs. 2018. Georgia farm gate value report 2017. Univ. Georgia Coop. Ext. Surv. Bull. AR 17-01.

Zebarth, B.J., S. Freyman, and C.G. Kowalenko. 1991. Influence of nitrogen fertilization on cabbage yield, head nitrogen content and extractable soil inorganic nitrogen at harvest. Can. J. Plant Sci. 71:1275-1280.

Zotarelli, L., P.J. Dittmar, N.S. Dufault, B. Wells, J. Desaeger, J.W. Noling, E.J. McAvou, Q. Wang, and C.F. Miller. 2019. Cole crop production, p. 35-52. In: P.J. Dittmar (ed.). Vegetable production handbook of Florida 2019-2020. Univ. Florida IFAS Ext. CV292. 